\title{
Forbidden links, trait matching and modularity in plant- hummingbird networks: Are specialized modules characterized by higher phenotypic floral integration?
}

\author{
Jaume Izquierdo Palma ${ }^{1}$, Maria del Coro Arizmendi ${ }^{\text {Corresp., }}{ }^{1}$, Carlos Lara ${ }^{2}$, Juan Francisco Ornelas ${ }^{3}$ \\ ${ }^{1}$ Laboratorio de Ecología, UBIPRO, Facultad de Estudios Superiores Iztacala, Universidad Nacional Autónoma de México, Tlalnepantla de Baz, Estado de \\ México, Mexico \\ ${ }^{2}$ Centro de Investigación en Ciencias Biológicas, Universidad Autónoma de Tlaxcala, San Felipe Ixtacuixtla, Tlaxcala, Mexico \\ 3 Departamento de Biología Evolutiva, Instituto de Ecología A.C., Xalapa, Veracruz, Mexico \\ Corresponding Author: Maria del Coro Arizmendi \\ Email address: coro@unam.mx
}

Background. Plant-pollinator mutualistic networks show non-random structural properties that promote species coexistence. However, these networks show high variability in the interacting species and their connections. Mismatch between plant and pollinator attributes can prevent interactions, while trait matching can enable exclusive access, promoting pollinators' niche partitioning and, ultimately, modularity. Thus, plants belonging to specialized modules should integrate their floral traits to optimize the pollination function. Herein, we aimed to analyze the biological processes involved in the structuring of plant-hummingbird networks by linking network morphological constraints, specialization, modularity, and phenotypic floral integration.

Methods. We investigated the understory plant-hummingbird network of two adjacent habitats in the Lacandona rainforest of Mexico, one characterized by lowland rainforest and the other by savanna-like vegetation. We performed monthly censuses to record plant-hummingbird interactions for two years (2018-2020). We also took hummingbird bill measurements and floral and nectar measurements. We summarized the interactions in a bipartite matrix and estimated three network descriptors: connectance, complementary specialization $\left(\mathrm{H}_{2}{ }^{\prime}\right)$, and nestedness. We also analyzed the modularity and average phenotypic floral integration index of each module.

Results. Both habitats showed strong differences in the plant assemblage and network dynamics but were interconnected by the same four hummingbird species, two Hermits and two Emeralds, forming a single network of interaction. The whole network showed low levels of connectance $(0.35)$ and high specialization $\left(\mathrm{H}_{2}{ }^{\prime}=0.87\right)$. Flower morphologies ranged from generalized to specialized, but trait matching was an important network structurer. Modularity was associated with morphological specialization. The Hermits Phaethornis longirostris and $P$. striigularis each formed a module by themselves, and a third module was formed by the less-specialized Emeralds: Chlorestes candida and Amazilia tzacatl. The floral integration values were higher in specialized modules but not significantly higher than that formed by generalist species.

Conclusions. Our findings suggest that biological processes derived from both trait matching and "forbidden" links, or nonmatched morphological attributes, might be important network drivers in tropical plant-hummingbird systems while morphological specialization plays a minor role in the phenotypic floral integration. The broad variety of corolla and bill shapes promoted niche partitioning, resulting in the modular organization of the assemblage according to morphological specialization. However, more

Peer] reviewing PDF | (2020:07:50913:4:0:NEW 25 Jan 2021) 
research adding larger datasets of both the number of modules and pollination networks for a wider region is needed to conclude whether phenotypic floral integration increases with morphological specialization in plant-hummingbird systems. 


\section{Forbidden links, trait matching and modularity in} plant-hummingbird networks: Are specialized modules characterized by higher phenotypic floral integration?

Jaume Izquierdo-Palma ${ }^{1}$, María del Coro Arizmendi ${ }^{1}$, Carlos Lara ${ }^{2}$, Juan Francisco Ornelas ${ }^{3}$

${ }^{1}$ Laboratorio de Ecología, UBIPRO, Facultad de Estudios Superiores Iztacala, Universidad Nacional Autónoma de México, Tlalnepantla de Baz, Estado de México, Mexico

${ }^{2}$ Centro de Investigación en Ciencias Biológicas, Universidad Autónoma de Tlaxcala, San Felipe Ixtacuixtla, Tlaxcala, Mexico

${ }^{3}$ Departamento de Biología Evolutiva, Instituto de Ecología A.C., Xalapa, Veracruz, Mexico

Corresponding author:

María del Coro Arizmendi

Avenida de los Barrios 1, Tlalnepantla de Baz, Estado de México, 54090, Mexico

Email address: coro@unam.mx

\section{Abstract}

Background. Plant-pollinator mutualistic networks show non-random structural properties that promote species coexistence. However, these networks show high variability in the interacting species and their connections. Mismatch between plant and pollinator attributes can prevent interactions, while trait matching can enable exclusive access, promoting pollinators' niche partitioning and, ultimately, modularity. Thus, plants belonging to specialized modules should integrate their floral traits to optimize the pollination function. Herein, we aimed to analyze the biological processes involved in the structuring of plant-hummingbird networks by linking network morphological constraints, specialization, modularity, and phenotypic floral integration. Methods. We investigated the understory plant-hummingbird network of two adjacent habitats in the Lacandona rainforest of Mexico, one characterized by lowland rainforest and the other by savanna-like vegetation. We performed monthly censuses to record plant-hummingbird interactions for two years (2018-2020). We also took hummingbird bill measurements and floral and nectar measurements. We summarized the interactions in a bipartite matrix and estimated three network descriptors: connectance, complementary specialization $\left(\mathrm{H}_{2}{ }^{\prime}\right)$, and nestedness. We also analyzed the modularity and average phenotypic floral integration index of each module. 
Results. Both habitats showed strong differences in the plant assemblage and network dynamics but were interconnected by the same four hummingbird species, two Hermits and two Emeralds, forming a single network of interaction. The whole network showed low levels of connectance (0.35) and high specialization $\left(\mathrm{H}_{2}{ }^{\prime}=0.87\right)$. Flower morphologies ranged from generalized to specialized, but trait matching was an important network structurer. Modularity was associated with morphological specialization. The Hermits Phaethornis longirostris and P. striigularis each formed a module by themselves, and a third module was formed by the less-specialized Emeralds: Chlorestes candida and Amazilia tzacatl. The floral integration values were higher in specialized modules but not significantly higher than that formed by generalist species. Conclusions. Our findings suggest that biological processes derived from both trait matching and "forbidden" links, or nonmatched morphological attributes, might be important network drivers in tropical plant-hummingbird systems while morphological specialization plays a minor role in the phenotypic floral integration. The broad variety of corolla and bill shapes promoted niche partitioning, resulting in the modular organization of the assemblage according to morphological specialization. However, more research adding larger datasets of both the number of modules and pollination networks for a wider region is needed to conclude whether phenotypic floral integration increases with morphological specialization in plant-hummingbird systems.

\section{Introduction}

Plant and animal species are integrated in complex networks of interdependencies forming ecological communities playing an important role in the generation of Earth's biodiversity (Bascompte \& Jordano, 2007). Plant-pollinator mutualistic networks are linked by trophic interactions where plants act as primary producers and animals as a special subset of primary consumers that feed on nectar and/or pollen (Bascompte \& Jordano, 2007; Waser et al. 1996). The strength of their interactions varies, resulting in large, complex networks in which interacting species impose reciprocal selective pressures as they interrelate over ecological and evolutionary time (Bascompte \& Jordano, 2007; Thomson \& Wilson, 2008; Waser et al., 1996). Over the last decade, the study of mutualistic networks has changed radically, along with the theory (Bascompte \& Jordano, 2007; Blüthgen et al., 2007; Olesen et al., 2007; Ings et al., 2009; Vázquez et al., 2009; Dalsgaard et al., 2011), and new powerful analytical tools have been proposed (Dormann, Gruber \& Fründ, 2008; Dormann \& Strauss, 2014). These advances have shown that non-random structural properties can be characterized by certain network metrics. For example, most interaction networks show a nested structure (i.e., specialists interact with subsets of species with which generalists also interact) and varying levels of connectivity among species. Both properties facilitate species coexistence by minimizing competition relative to facilitation, supporting greater biodiversity (Bascompte et al., 2003; Olesen et al., 2006; Verdú \& Valiente-Banuet, 2008; Bastolla et al., 2009; Sugihara \& Ye, 2009). Furthermore, most ecological networks are strongly asymmetric (i.e., a plant species might heavily depend on a pollen-vector species that, in turn, is only weakly dependent on that plant species). Thus, the 
community is structured around a central core of generalists, offering robustness and resilience to the random loss of species (Vázquez \& Aizen 2003; Bascompte, Jordano \& Olesen, 2006; Guimarães et al., 2006; Blüthgen et al., 2007; Bascompte \& Jordano, 2013).

Although the discussion on the architecture of mutualistic networks is quite settled, the underlying structuring mechanisms are still being debated (Maruyama et al., 2014; VizentinBugoni, Maruyama \& Sazima, 2014; Araujo et al., 2018). Mutualistic networks tend to be very heterogeneous in the number of interacting species at each level and the distribution of their connections, such as, for example, between animal-dispersed fruits and their dispersers or animal-pollinated angiosperms and their pollinators (Bascompte \& Jordano, 2007). Two major biological mechanisms that influence the structure of networks are the "complementary traits" and "barrier traits" (Santamaría \& Rodríguez-Gironés, 2007). For complementary traits, the interaction is determined by the similarity between the reward that the plant has to offer and the resource that the pollinator seeks. This mechanism can progressively generate co-specialization. For example, flowers that are mainly pollinated by birds are red in color, matching the perceptual system of their avian pollinators who show a preference for this colour when looking for nectar resources (Niovi Jones \& Reithel, 2001). For the mechanism of barrier traits, the interaction is related to the ability of the pollinator to reach the reward offered by the flower. Only those pollinators whose traits allow them to overcome the floral barriers are able to access the reward. For example, Hermit hummingbirds with typically long and curved bills have access to flowers with long and curved corolla tubes that hummingbird species with short and straight bills cannot access (Maglianesi et al., 2014). Consequently, competition for shared floral resources is reduced (Feinsinger, 1976; Ings et al., 2009; McGuire et al., 2009; Abrahamczyk \& Kessler, 2010; Maglianesi et al., 2014). These exploitation barriers imposed by the mismatch of biological attributes lead to a decrease in the connectivity and/or strength of the interactions in ecological networks can be called "forbidden links" (Santamaría \& Rodríguez-Gironés, 2007; Olesen et al., 2011).

Species abundances can be as important or even more important as species traits in structuring the ecological interaction networks of local communities (e.g., common in insect-pollination networks; Vázquez, Chacoff \& Cagnolo, 2009). However, plant-hummingbird mutualistic networks are considered a specialized system, particularly those located near the Equator due to higher productivity and the relatively stable and predictable availability of resources throughout the year (Feinsinger \& Colwell, 1978; Dalsgaard et al., 2011; Belmaker, Sekercioglu \& Jetz, 2012; Zanata et al., 2017). Several studies have shown that mismatches in species morphology and phenology play a major role in structuring interactions in plant-hummingbird systems (Stiles, 1978; Lara, 2006; Maglianesi et al., 2014; Maruyama et al., 2014; Vizentin-Bugoni et al., 2014; Sonne et al., 2019). Hummingbird clades have characteristic morphologies that influence resource use, flight capabilities, competitive skills and environmental filtering, important mechanisms structuring hummingbird communities (Rodríguez-Flores et al., 2019).

Furthermore, hummingbird morphological traits, such as bill length and curvature and body mass, have also been hypothesized to play a role in the specialization of hummingbird 
118

119

120

121

122

123

124

125

126

127

128

129

130

131

132

133

134

135

136

137

138

139

140

141

142

143

144

145

146

147

148

149

150

151

152

153

154

155

156

157

interactions. Meanwhile, corolla length and curvature and nectar volume are floral traits associated with the specialization of hummingbird-pollinated plants (Maruyama et al., 2014, 2018; Maglianesi et al., 2014, 2015; Dehling et al., 2016). Thus, specialization in trophic resources' use by hummingbird assemblages, which vary in its type and/or its strength, can arise in niche segregation of the community due to the differential access to flowers (Feinsinger \& Colwell, 1978).

The extent to which connectivity is limited by both morphological mismatches and spatiotemporal constraints often results in resource segregation, leading to niche partitioning and, consequently, a modular structure in ecological networks. Network modularity reflects the tendency of a set of species to interact predominantly with species within the set and less frequently with species in other sets. Modularity implies that species can be grouped (i.e. modules) in such a way that weakly interlinked subsets of species are strongly connected internally (Olesen et al., 2007). Modules can provide information on the dynamics of ecological communities by identifying specialized functional groups of pollinators and floral traits (Newman, 2006; Olesen et al., 2007; Danieli-Silva et al., 2012; Dormann \& Strauss, 2014; Maruyama et al., 2014). Some studies support the idea that modularity increases with the increased specialization of the interacting species (Lewinsohn et al., 2006; Guimarães et al., 2006) and is positively related with network size (Olesen et al., 2007). Thus, in little-connected and highly nested networks, which are common in the tropics (Olesen \& Jordano, 2002), there is a higher probability of modularity (Fortuna et al., 2010).

Specialized modules drive strong plant-pollinator relationships, leading to the diffuse coevolution of complementary morphological traits (Sazatornil et al., 2016). Furthermore, selection imposed by pollinators can be an important mechanism shaping the patterns of variation and covariation of floral traits, particularly in plant species with specialized pollination. Such is the case in the Phaethornis-Heliconia pollination system (Armbruster, 1991; Fenster, 1991; Herrera et al., 2002; Pérez et al., 2007; Ordano et al., 2008). In this context, flowers can be seen as suites or units of traits that require a precise configuration and arrangement of their sexual organs for proper pollination (Bissell \& Diggle, 2008). From this multi-trait view, some authors have argued that selection imposed by specialized pollinators reduces phenotypic variability and favors the integration of subsets of floral traits (Pleiades), i.e., correlations among traits within functional units usually involved in one ecological function (Berg, 1960; Stebbins, 1970; Conner \& Via, 1993; Rosas-Guerrero et al., 2011). However, other factors may be linked with phenotypic floral integration, such as the breeding system (Anderson \& Busch, 2006; RosasGuerrero et al., 2011) and developmental-genetic factors (Conner, 2002; Smith \& Rausher, 2008). Nonetheless, the relationship between specialization and niche partitioning in hummingbird assemblages and its possible effects on the phenotypic floral integration of interacting plant species are poorly understood (Berg, 1960; Stebbins, 1970; Conner \& Via, 1993; Rosas-Guerrero et al., 2011).

In this study, we assessed the association among biological processes involved in the structuring of plant-hummingbird networks, niche segregation by ecological specialization, and 
158

159

160

161

162

163

164

165

166

167

168

169

170

171

172

173

174

175

176

177

178

179

180

181

182

183

184

185

186

187

188

189

190

191

192

193

194

195

196

197

phenotypic floral integration of the plant assemblages. We used the phenotypic floral integration index as a measurable estimate of the magnitude and pattern of covariation among sets of functionally related floral traits to obtain new insights into the link between modularity and specialization in plant-hummingbird mutualistic networks (Ordano et al., 2008; Rosas-Guerrero et al., 2011; Dormann \& Strauss, 2014). To achieve this, we investigated the network architecture by descriptors commonly used in similar studies and identified the possible underlying biological processes, i.e., trait matching and forbidden links. Then, we analyzed the modularity and floral integration index of each module to identify patterns of covariation. In particular, we examined the understory plant-hummingbird mutualistic networks in two distinct adjacent habitats in Mexico, addressing the following questions: (1) Are there differences between the two habitats in the composition of interacting species and their network metrics? (2) What is the main network structuring each habitat? And, (3) is there a relationship between module specialization and phenotypic floral integration? To our knowledge, the linking of network morphological constraints, specialization, modularity, and phenotypic floral integration is a new approach in the study of plant-hummingbird interaction networks.

\section{Materials \& Methods}

\section{Study area}

Fieldwork was carried out at the Chajul Biological Station located in the Montes Azules Biosphere Reserve $\left(16^{\circ} 06^{\prime} \mathrm{N}\right.$; $\left.90^{\circ} 56^{\prime} \mathrm{E}\right)$ within the Lacandon region in southern Mexico a few kilometers from the Guatemalan border. The study area covers an extension of $\sim 331,200$ ha and is situated from 150 to 1,500 meters above sea level (m a.s.1.). Mean rainfall in Chajul is around $3000 \mathrm{~mm}$, of which ca. 70\% is concentrated during the rainy season from May to December. The dry season occurs from January to April. The mean annual temperature is $22.5^{\circ} \mathrm{C}$ (Carabias, De la Maza \& Cadenas, 2015). The dominant vegetation around the field station is lowland evergreen tropical rainforest (hereafter "rainforest" habitat) with some variability influenced by the soil properties and proximity to water bodies. Near streams and rivers, there is riparian vegetation and sections of flooded plains. In areas surrounding the field station where the anthropic impact has been more intense in recent times, the vegetation mainly consists of secondary forest and abandoned fields in different stages of ecological succession. There is also some hilly terrain (highest elevation: 230 m.a.s.1) with thin and poor soils, and the vegetation here is savanna-like with low and scattered trees and an understory characterized by abundant grass (Scleria melaleuca; hereafter "savanna" habitat) (Miranda \& Hernández, 1973; Rzedowski \& Huerta, 1994; Siebe et al., 1996). We collected data from January 2018 to January 2020 along trails $6700 \mathrm{~m}$ long in both study habitats.

\section{Phenology of hummingbirds and their plants}

At monthly intervals, we recorded the hummingbird species and their numbers along six study trails in both habitats. Walking censuses began around 7:00 AM and ended at 1:30 PM. All hummingbird-pollinated plant species (individuals or floral patches) flowering within $2.5 \mathrm{~m}$ on 
198

199

200

201

202

203

204

205

206

207

208

209

210

211

212

213

214

215

216

217

218

219

220

221

222

223

224

225

226

227

228

229

230

231

232

233

234

235

236

237

each side of the trails were counted at a maximum height of $5 \mathrm{~m}$. We focused on the understory plant community for logistical reasons. Flowering plants in the canopy are difficult to see from the ground, which may result in an underestimation of the number of plant individuals and interactions with their pollinators. Binoculars (Nikon $10 \times 42$ ) and a field guide were used to identify hummingbirds (Arizmendi \& Berlanga, 2014), and plant specimens were identified at the Chajul Biological Station herbarium. The scientific names of plants were validated using "The Plant List" online database (www.theplantlist.org) and hummingbird scientific names using the IOC World Bird List (www.worldbirdnames.org).

\section{Floral measures and bill morphology}

Because hummingbirds commonly visited the flowers of the plant species we observed during the censuses, we quantified several floral traits presumed to be associated with hummingbird pollinator attraction and pollen transfer efficiency (Wolf, Stiles \& Hainsworth, 1976; Stiles, 1995). The flower morphology was characterized by measuring the corolla length and curvature, as these are the primary constraints determining the ability of hummingbirds to reach the nectar. We measured the effective corolla length (i.e., distance from the nectary to the distal portion of the flower, which determines how far the bill of the feeding bird fits into the flower) (Wolf, Stiles \& Hainsworth, 1976). In addition, we calculated the flower curvature following similar methodology used in hummingbird bills (Stiles, 1995; Rico-Guevara \& Araya-Salas, 2015). We calculated a corolla curvature index as the arc:chord ratio of the corolla. Arc length was measured following the dorsal profile of the corolla from the calyx to the corolla tip, and the chord was measured as the straight-line distance from the calyx to the corolla tip. These measures were taken from lateral photographs using the ImageJ software (Schneider et al., 2012). Because the placement of pollen on the vector and its subsequent reception on the stigma is crucial to plant fitness, we measured the average stamen length and style length. For each plant species recorded in both habitats, we measured from 2 to 180 flowers collected from at least two individuals. Accumulated nectar was also quantified to determine reward availability for hummingbirds. From each plant species, 2-30 buds about to open were selected and placed in mesh bags (1-mm bridal tulle) to exclude hummingbird visitors and allow nectar to accumulate. After the flowers opened, the accumulated nectar was extracted, and the nectar was removed and measured after $24 \mathrm{~h}$ of nectar accumulation using calibrated micropipettes $(5 \mu \mathrm{L})$ and a digital caliper (error: $0.1 \mathrm{~mm}$ ). The sugar concentration (percentage sucrose) was measured by a handheld pocket refractometer (range concentration $0-32^{\circ}$ Brix units $\left({ }^{\circ} \mathrm{Bx}\right)$; Atago, Tokyo, Japan). To characterize the main floral types of the whole plant assemblage, we performed a principal components analysis (PCA) of the measured floral traits (morphology and nectar) after discarding highly correlated variables through a correlation analysis.

The hummingbirds' bill morphology was measured as the length of the exposed culmen and its curvature from voucher specimens housed at the collection of the Museo de Zoología, Facultad de Ciencias, Universidad Nacional Autónoma de México (MZFC, UNAM) (Phaethornis longirostris $[n=30], P$. striigularis $[n=20]$, Amazilia tzacatl $[n=30]$, and Chlorestes candida 
$238[n=28]$ ). As hummingbirds can project their tongues to drink nectar (Paton \& Collins, 1989),

239 bill measurements that ignore tongue extension can underestimate birds' capacity to access

240 nectar. Because precise measurements of tongue length are unavailable for different

241 hummingbird species, we added one-third to the bill length for each species (Vizentin-Bugoni,

242 Maruyama \& Sazima, 2014). To examine differences in bill shape, we calculated a bill curvature

243 index as the arc:chord ratio of the exposed culmen (maxillary curvature) (Stiles, 1995; Rico-

244 Guevara \& Araya-Salas, 2015). Arc length was measured following the dorsal profile of the bill

245 from the feathered base to the tip, and the chord was measured as the straight-line distance from

246 the feathered base to the tip (Phaethornis longirostris $[n=18]$, P. striigularis $[n=14]$, Amazilia

247 tzacatl $[n=13]$, and Chlorestes candida $[n=20])$. These measures were taken from lateral

248 photographs of the complete bill using the ImageJ software (Schneider et al., 2012).

249 Furthermore, we obtained the average measures of total body weight to relate them with

250 agonistic behavior and nutritional requirements (Phaethornis longirostris $[n=15]$, P. striigularis

$251[n=11]$, Amazilia tzacatl $[n=10]$, and Chlorestes candida $[n=12])$. To obtain a closer

252 relationship between the trait match of plant species and their hummingbird visitors, we

253 calculated the average of each floral trait of the flowering plants visited by the hummingbird

254 species. Then, comparisons were made with the average bill length and curvature.

255

256

Plant-hummingbird interactions

257

We built the plant-hummingbird mutualistic networks from a plant-centered approach (Jordano,

258 1987; Bosch et al., 2009). We did not record other pollinator interactions despite have been reported that many plants visited by hummingbirds are also visited by insects (Dalsgaard et al., 2009). Nevertheless, this fact should not affect to test our hypotheses due to the high specialization of our study system. Plant-insect pollination studies require another methodology with closer observations and adapted to the daily foraging activity of each invertebrate species. Because our study was based on mutualistic relationships, we only considered hummingbirds as potential pollinators. We recorded legitimate hummingbird visits, i.e., when hummingbirds contacted the reproductive structures of the flowers. Each visit was defined as the moment a hummingbird probed one flower until it left the flowering plant/patch. We conducted from 8 to $50 \mathrm{~h}$ focal observations of each plant species (Vizentin-Bugoni et al., 2016). Most observations were conducted by video recording (GoPro Hero5), but in some cases (i.e., large floral patches or epiphytes with difficult access), we used binoculars (Nikon $10 \times 42$ ) to prevent underestimating the interactions. The observations were conducted from 07:00 AM to 11:30 AM, the time period of maximum foraging activity based on preliminary observations. Whenever possible, we conducted the observations at different plant individuals and locations to capture maximum variability. We observed a total of $657 \mathrm{~h}$ of plant-hummingbird interactions.

274

\section{Analysis of interaction networks}

276 We summarized the plant-hummingbird interactions in a bipartite matrix with each cell indicating the frequency of interactions. Because the two habitats are adjacent, they can form a 
278

279

280

281

282

283

284

285

286

287

288

289

290

291

292

293

294

295

296

297

298

299

300

301

302

303

304

305

306

307

308

309

310

311

312

313

314

315

316

317

single network. For this reason, we built a single interaction network for both habitats. However, to have a glimpse of the possible underlying biological processes modeling interactions in each habitat, we also built two separate interaction networks corresponding with the rainforest and savanna communities. Using these matrices, we estimated several network metrics of structure and specialization, which are detailed at following: (1) Connectance was calculated as the proportion of possible links in the network that are actually realized. If nonmatching species traits can prevent the occurrence of certain interactions (forbidden links), connectance is an estimate of how interactions are constrained in the communities. (2) Complementary specialization $\left(\mathrm{H}_{2}{ }^{\prime}\right)$ estimates the exclusiveness of interactions considering the ecological specialization of a species (i.e., how connected a species is) and how these interactions differ among species. The $\mathrm{H}_{2}$ ' index is useful for comparing ecological networks, as it is less affected by community size or sampling intensity (Blüthgen et al., 2007). (3) Nestedness was calculated using the ANINHADO software (Guimarães \& Guimarães, 2006). We used two estimators, the NODF index, which uses qualitative presence/absence data, and wNODF, which considers quantitative interaction data (Almeida-Neto et al., 2008; Almeida-Neto \& Ulrich, 2011). (4) Modularity (Q), as defined above, was estimated for both quantitative and qualitative matrices. For the quantitative matrices, we used the QuanBiMo optimization algorithm (Dormann \& Strauss, 2014). As the QuanBiMo algorithm has an iterative searching algorithm (values can slightly differ between runs), we chose the highest values from 10 independent runs. The modularity of the qualitative matrix was estimated in MODULAR (Marquitti et al., 2014), a stochastic algorithm, using Barber's metric for bipartite networks (Barber, 2007) and following the recommended program settings (Marquitti et al., 2014; Appendix 3). We estimated the significance of each run against 100 null matrices obtained with two null models: the ErdösRényi (ER) model (Marquitti et al. 2014) and one proposed by Bascompte et al. (2003). We also ran a modularity analysis considering both habitats together. If the habitats functioned as separated units, separate modules corresponding with each community would be generated.

To evaluate the statistical significance of the estimated network metrics, we compared the observed values to 1000 random values calculated from the null matrices. These matrices were generated using a randomization algorithm that conserves the total number of interactions per row and column in the matrix (Patefield's r2dtable algorithm). Such a null model is not prone to type I errors (Dormann, Gruber \& Fründ, 2008). The network indices (connectance, $\mathrm{H}_{2}{ }^{\prime}$, NODF, wNODF, and Q) were expressed as z-scores (observed - mean(null) / sd(null)), and the statistical significance was assessed by Z-tests. The interaction networks and networks metrics were built and estimated using the bipartite package version 2.11 (Dormann, Gruber \& Fründ, 2008) in R software ( $R$ Development Core Team, 2018).

\section{Analysis of phenotypic floral integration}

To obtain a measurable estimate of the magnitude (i.e., degree to which the traits are tied) and pattern (i.e., arrangement of the relationships among traits) of covariation among sets of functionally related floral traits, we estimated the phenotypic integration index (PINT). We also 
318

319

320

321

322

323

324

325

326

327

328

329

330

331

332

333

334

335

336

337

338

339

340

341

342

343

344

345

346

347

348

349

350

351

352

353

354

355

356

357

expressed the PINT as a percentage depending on the maximum possible integration levels (RelPINT). PINT and RelPINT were estimated using the package PHENIX (Torices \& MuñozPajares, 2015) in R software (R Development Core Team, 2018); both are based on a correlation matrix following Wagner (1984). We calculated the PINT for each plant species (except those lacking sufficient data) and the average PINT of plants in both communities. Since flowers with floral traits of a similar size, i.e., corolla, stamen, and style length, produce high PINT values simply by correlation, we included nectar metrics as floral traits. The reward traits were added to mitigate high PINT values unrelated with floral specialization. We obtained the average PINT across the species of each module of the overall interaction network to link phenotypic floral integration patterns and ecological specialization and assessed differences across these species with one-way ANOVAs. We also compared the average PINT across habitats following the same procedure.

\section{Results}

\section{Hummingbirds and their floral resources}

The plant-hummingbird data set comprised a total of 3,403 interactions between 26 plant species belonging to eight families and four hummingbird species. In the rainforest habitat, we recorded 1069 interactions with 18 plant species belonging to eight families (Acanthaceae, Bromeliaceae, Costaceae, Fabaceae, Heliconiaceae, Malvaceae, Marantaceae, Rubiaceae) (Figs. 1, 2). In the savanna habitat, we recorded 953 interactions with eight plant species belonging to two families (Bromeliaceae and Rubiaceae) (Figs. 1, 2). The hummingbird assemblage was the same in both communities and composed of year-round species, including two species in the Emeralds clade (Chlorestes candida and Amazilia tzacatl) and two in the Hermits clade (Phaethornis longirostris and Phaethornis striigularis). In the rainforest habitat, we recorded three additional species: Anthracothorax prevostii, Heliothryx barroti, and Phaeochroa cuvierii. However, they only made illegitimate visits, acting as nectar robbers. For this reason, these species were not included in the mutualistic network described below. The plant assemblages were distinct in each community, with no shared species, yet the hummingbird species were the same. Thus, both habitats are considered as a single interaction network interconnected by the hummingbirds.

Despite we did not sample other plant-pollinator interactions, insects as floral visitors were rare in general and acted mainly as illegitimate visitors based on our observations. Most of the plant assemblage exhibited a clear ornithophilic syndrome (acting by itself as an insect deterrent) but some plant species showed less strict floral barriers against generalized pollinators, such as Catopsis berteroniana. From the video recordings we observed legitimate visits by insects in Calathea lutea and Stromanthe macrochlamys, both from the Marantaceae family. Despite Phaethornis striigularis was the only hummingbird visitor registered in both of these plant species, we also observed insects (butterflies, bees, and hoverflies) visiting and even opening the flowers using their complex explosive pollination mechanism (Ley \& Bockhoff, 2009). We also noticed abundant legitimate visits by different butterfly species in Psychotria poeppigiana. Thus, hummingbirds acted as occasional visitors to those species. We also observed some visits in 
358

359

360

361

362

363

364

365

366

367

368

369

370

371

372

373

374

375

376

377

378

379

380

381

382

383

384

385

386

387

388

389

390

391

392

393

394

395

396

397

Costus ruber by euglossine bees, but we could not determine whether they were legitimate or illegitimate. In some plant species, such as Heliconia librata and Heliconia aurantiaca, we observed small butterflies, ants and small bees (mainly stingless bees of the genus Trigona) obtaining nectar from the bracts, acting as nectar robbers, but none of these observations were considered in this study.

\section{Plant-hummingbird interaction networks}

The complete network had low levels of connectance $(0.35$, z-score $=-2.82 . \mathrm{p}=0.005)$ and high levels of $\mathrm{H}_{2}$ ' compared to the null matrices $(0.87$, z-score $=15.97, \mathrm{p}=<0.0001)$, showing ecological specialization between hummingbirds and plants. The values of NODF (38.33, z-score $=-3.960, \mathrm{p}=0.002)$ and $\operatorname{wNODF}(11.41, \mathrm{z}$-score $=-3.89, \mathrm{p}=<0.001)$ were statistically significant, showing lower levels of nestedness than expected. The $\mathrm{Q}$ value $(0.51, \mathrm{z}$-score $=$ 16.43, $\mathrm{p}<0.001)$ indicated significant modularity that was higher than expected. We obtained three modules: one formed by Phaethornis longirostris, another by Phaethornis striigularis, and a final formed by the two Emerald species, Chlorestes candida and Amazilia tzacatl. The modules did not separate the habitats, but the habitats were related with the ecological specialization of species. The module formed by $P$. longirostris only included plants species from the rainforest assemblage (Fig. 3, Supplemental Table S1). As we obtained the same modules using the QuanBiMo and MODULAR software, we only used the results from QuanBiMo because our network was quantitative.

The Hermits were the main clade of floral visitors. Phaethornis longirostris visited 16 plant species and was the only hummingbird species recorded in 11 of these, all belonging to the rainforest assemblage (Fig. 1, 2). The strength of the interaction (represented by the number of visits/h) between $P$. longirostris and Heliconia wagneriana is remarkable, with a mean of 47.44 visits/h, far above any other interaction. This visitation rate can be explained by the fact that $H$. wagneriana grows in large patches and $P$. longirostris is the only hummingbird capable of obtaining nectar from their long, curved flowers (Fig. 4). Thus, they remained near the $H$. wagneriana patches during the flowering period, taking advantage of their abundance despite being considered trapliners. Phaethornis striigularis visited the flowers of 15 plant species and was the only visitor recorded to eight of them, five of which were in the rainforest and two in the savanna assemblage (Fig. 1, 2). Amazilia tzacatl and Chlorestes candida visited seven and six plant species, respectively. These Emeralds always acted as generalist foragers of generalist plants species in both habitats. This is probably due to the trait mismatch between their bills and the specialized corollas, so they were not the only visitors recorded to any of the flowering plants.

When dividing the complete network by habitat, each community differed considerably in its network topography. The plant-hummingbird interaction network in the rainforest habitat had a low level of connectance $(0.35$, z-score $=-2.88, \mathrm{p}=0.004)$ and high level of $\mathrm{H}_{2}{ }^{\prime}(0.83$, z-score $=$ $4.95, \mathrm{p}<0.0001)$, similar to the complete network. The NODF $(25.77$, z-score $=-0.18, \mathrm{p}=0.86)$ 
398

399

400

401

402

403

404

405

406

407

408

409

410

411

412

413

414

415

416

417

418

419

420

421

422

423

424

425

426

427

428

429

430

431

432

433

434

435

436

437

was not statistically significant, yet the wNODF $(10.15, \mathrm{z}$-score $=-2.32, \mathrm{p}=0.02)$ was lower than expected. In the rainforest habitat, Phaethornis longirostris was the main floral visitor to 13 plant species followed by Phaethornis striigularis, which visited seven species (Fig. 1). On the other hand, Amazilia tzacatl and Chlorestes candida only visited three or two plant species, respectively. The plant-hummingbird interaction network in the savanna habitat showed higher levels of connectance compared to the rainforest community, although these were lower than expected $(0.59, \mathrm{z}$-score $=-2.64, \mathrm{p}=0.009)$. The $\mathrm{H}_{2}$ ' value $(0.47$, $\mathrm{z}$-score $=3, \mathrm{p}=0.003)$ was intermediate, suggesting less niche specialization than in the rainforest community (Fig. 1). The $\operatorname{NODF}(70.59, \mathrm{z}$-score $=0.71, \mathrm{p}=0.47)$ and $\operatorname{wNODF}(41.91, \mathrm{z}$-score $=1.37, \mathrm{p}=0.17)$ were higher but not significantly higher as compared to the rainforest network. In the savanna habitat, $P$. striigularis was the main visitor to eight plant species. On the other hand, we only recorded a few visits of $P$. longirostris to three plant species, with a visitation rate of 0.02 to $0.10 \mathrm{visits} / \mathrm{h}$. For this reason, the latter species can be considered a rare visitor to the savanna habitat. Unlike the rainforest interaction network, the two Emerald species had a greater role as floral visitors and behaved as territorial in the savanna habitat, as indicated by the strength of some of their floral interactions (Fig. 1).

\section{Hummingbird-plant trait matching}

From the PCA analysis, we obtained three principal components that accumulated $88.18 \%$ of the total variance (Table 1, 2). Floral traits selected after the correlation analysis were corolla length, corolla curvature, nectar volume, and nectar concentration (Supplemental Table S2). The first component was related with straight, small-sized flowers with dilute nectar in small quantities (PC1: $50.5 \%$ of total variance). The main plant families matching with this category were Bromeliaceae (4 species), Rubiaceae (2), Acanthaceae (1), and Marantaceae (1). Fifty-three percent were from the rainforest and the remaining 47\% from the savanna. Eighty percent of the plant species were visited by Phaethornis striigularis, $20 \%$ by P. longirostris, $40 \%$ by Amazilia tzacatl, and $33 \%$ by Chlorestes candida. The second factor was related with small flowers with high nectar concentration (PC2: 19.5\% of total variance). Only two species belonged to this factor, Calathea lutea and Stromanthe macrochlamys, both found in the rainforest habitat. As explained above, both of these plant species were visited mainly by insects apart from Phaethornis striigularis. Lastly, the third factor was related with flowers with moderate corolla curvature and low nectar volume (PC3: 18.18\% of the total variance). The associated plant species mainly were Bromeliaceae (5 species) and Acanthaceae (3). Seventy-five percent were from the rainforest and $25 \%$ from the savanna. In this case, the two Hermit species were the only visitors, and they visited the same number of plant species.

We observed trait matching between plants (floral traits) and hummingbirds (bill morphology) mainly in species with specialized interactions (Fig. 4, Table 3). Plant species exclusively visited by Phaethornis longirostris were differentiated by their long and curved corollas (i.e., Heliconia species), and the specialized morphology of this hummingbird species enabled it to access the nectar. The average bill length of $P$. longirostris was $53.3 \pm 2.88 \mathrm{~mm}(n=30)$, practically 
438

439

440

441

442

443

444

445

446

447

448

449

450

451

452

453

454

455

456

457

458

459

460

461

462

463

464

465

466

467

468

469

470

471

472

473

474

475

476

477

identical to the average corolla length of the flowers they exclusively visited. This Hermit species had the most curved bill in the study area $\left(31.82^{\circ} \pm 4.33, n=18\right)$, and the flowers it visited also had higher curvature in their corollas. However, its bill was approximately three times more curved than the corolla of its visited flowers. In addition, this Hermit species was the largest hummingbird of the assemblage, with an average body weight of $5.50 \mathrm{~g}( \pm 0.83, n=15)$, which seems related with the highest average nectar volume and sugar concentration of its visited plant species. We also obtained trait matching between Phaethornis striigularis and the flowers they exclusively visited, mainly small- to medium-sized flowers with some degree of curvature (higher than $\left.5^{\circ}\right)$. The average bill length of $P$. striigularis was $27.39 \mathrm{~mm}( \pm 1.23, n=$ $20)$, close to the average corolla length of its visited flowers. The average bill curvature was $25.21^{\circ}( \pm 3.40, n=14)$ although, as observed with the other Hermit species, the bill curvature was higher than the average corolla curvature. Phaethornis striigularis was the smallest hummingbird of the assemblage, with an average body weight of $2.61 \mathrm{~g}( \pm 1.32, n=11)$. The average nectar volume of the flowers they exclusively visited was approximately 4.5 times lower than those visited by $P$. longirostris. However, the sugar concentration remained similar. Finally, small- to medium-sized flowers with less than $5^{\circ}$ of corolla curvature were visited by several hummingbird species, mainly by the Emerald species and $P$. striigularis.

Seven out of 26 plant species received visits by two or more hummingbird species. In these seven species the average corolla length was shorter than the bill length of the two Emerald species, which was $23.52 \mathrm{~mm}( \pm 1.53, n=28)$ in Chlorestes candida and $27.9 \mathrm{~mm}( \pm 1.97, n=$ 30 ) in Amazilia tzacatl, similar to the average bill length of $P$. striigularis. The main difference of the Emerald species was related to the bill curvature, with these species having the straighter bills of the assemblage, or an average bill curvature of $17.84^{\circ}( \pm 3.13, n=20)$ for $C h$. candida and $16.75^{\circ}( \pm 2.93, n=13)$ for $A$. tzacatl. Correspondingly, the flowers they visited were straight or had little curvature in their corollas. Regarding body weight, the two Emerald species had intermediate values between the two Phaethornis species, or $3.35 \mathrm{~g}( \pm 0.45 \mathrm{~g}, n=12)$ for Ch. candida and $4.93 \mathrm{~g}( \pm 0.96 \mathrm{~g}, n=10)$ for $A$. tzacatl. The average nectar volume of the flowers they visited was similar to that of the flowers visited by $P$. longirostris, although the average sugar concentration was lower, corresponding with $22.55^{\circ} \mathrm{Bx}( \pm 2.47, n=123)$ (Table 3).

\section{Phenotypic floral integration}

We obtained phenotypic integration values for 22 out of the 26 plant species (Fig. 3,

Supplemental Table S1). The average floral integration of the plant assemblage in our study site (with nectar variables) was $19.38 \%$, around the average $(21.5 \%)$ for the angiosperms examined by Ordano et al. (2008). Sufficient data were not available for the following plant species: Aechmea tillandsioides, Billbergia viridiflora, Bromelia pinguin, and Tillandsia pruinosa. In comparing the average PINT of the plant assemblages of each habitat, the savanna community had a slightly higher value (rainforest $=0.80, n=15$; savanna $=0.92, n=7$ ), but it was not statistically significant $(\mathrm{F}=0.35, \mathrm{df}=1, \mathrm{p}=0.56)$. The results of the PINT analysis across 
478

479

480

481

482

483

484

485 486

487

488

489

490

491

492

493

494

495

496

497

498

499

500

501

502

503

504

505

506

507

508

509

510

511

512

513

514

515

516

modules suggest that specialized modules had higher values, even though they were statistically similar. The plant species integrated to the Phaethornis longirostris module had higher values $(\mathrm{PINT}=0.92$, RelPINT $=22.79 \%, n=9)$, followed by those integrated to the Phaethornis striigularis module $(\mathrm{PINT}=0.82$, RelPINT $=20.50 \%, n=8)$. Meanwhile, the module integrated by the two Emerald species had lower values (PINT $=0.74$, RelPINT $=20.36 \%, n=5$ ), although the results from the ANOVA test showed that these differences were not significant $(\mathrm{F}=0.25$, df $=2, p=0.79)$. Therefore, the relationship between the ecological specialization of modules and their phenotypic floral integration index was unclear according to these data (Fig. 3).

\section{Discussion}

As expected, we found that forbidden links and trait matching promote modularity in the planthummingbird system of the Lacandona rainforest. However, the low number of modules and small pollination networks likely affected the non-significant relationship between ecological specialization and phenotypic floral integration.

Our results suggest that the adjacent habitats, interconnected by the same hummingbird species, did not function as separate units but instead form a single plant-hummingbird interaction network. Thus, it is possible that two plants from the rainforest and savanna are more intimately linked through their shared hummingbird species than two plants from the same habitat with different hummingbird pollinators. According to Bergamo et al. (2017), the overlap of pollinators can influence the visitation patterns and potentially lead to indirect interactions (e.g., facilitation or competition), especially with plants with a similar floral phenotype. Nevertheless, we found that strong habitat differences in plant composition might impact some of the structural parameters when analyzed separately. The rainforest habitat was characterized by plant species with long and curved corollas, whereas small- and medium-sized flowers with straight corollas or with a little curvature (even non-ornithophilous) characterized the savanna habitat (Arizmendi \& Ornelas, 1990; Araújo, Maruyama et al., 2013; Sazima \& Oliveira, 2013). The lack of flowers with long corollas is probably the cause of the almost complete absence of Phaethornis longirostris in the savanna habitat. Floral morphology has been shown to play an important role in tropical hummingbird-pollination systems, influencing not only the visitors but also the strength of their interactions. For example, in plant-hummingbird interactions on the West Indies, most specialized hummingbird-pollinated plants were found in highlands and were mainly pollinated by large, long-billed hummingbirds, whereas highly generalist plants were found in dry and warm lowlands and were pollinated by small, short-billed hummingbirds in addition to insect species (Dalsgaard et al., 2009). In another case study in Brazil, Maruyama et al. (2014) highlighted the importance of traits as determinants of interaction frequencies and associated them with morphological specialization and habitat occupancy, the main network structurers, in a Neotropical savanna/forest network.

In relation to network metrics, our results showed low levels of connectance and high complementary specialization in accordance with other mutualistic networks in tropical forests 
517 (Vizentin-Bugoni et al., 2014; Maglianesi et al., 2015; Araujo et at., 2018). The relationship 518 between plants and hummingbirds resulted highly asymmetric: Many plants only received visits 519 from a single hummingbird species, whereas some hummingbirds visited more than ten plant 520 species. However, reciprocally specialized interactions are rare in nature, even in networks 521 considered specialized (Joppa et al., 2009). Despite the low number of hummingbird species in 522 the habitats sampled, they showed high variation in their morphological traits such as body size, 523 bill length, and foraging behavior. Morphological and behavioral differences among species 524 enabled them to be classified into three roles in the organization of the community: Phaethornis 525 longirostris is a high-reward trapliner, and $P$. striigularis is a low-reward trapliner (frequently acting as a nectar robber when it is unable to access the nectar reward). And, depending on the patch quality, Chlorestes candida and Amazilia tzacatl act as territorial and generalist species (Feinsinger \& Colwell, 1978). Therefore, in our network, both trait matching and forbidden links could be playing a major role in niche partitioning, shaping the network structure (Dalsgaard et al., 2011). Morphological resemblance has been found to allow the exclusive access of some species (e.g., Phaethornis species) to the most specialized flowers (Bergamo et al., 2018; Sonne et al., 2019; Sonne et al. 2020). Moreover, forbidden links regulated the interactions of the two Emerald species with less specialized bill morphologies that were unable to access flowers with long and curved corollas. Thus, variation in feeding strategies and degrees of specialization with respect to specific floral resources might be crucial for the coexistence of hummingbird species (Abrahamczyk \& Kessler, 2015; Maglianesi et al., 2015; Sonne et al., 2016; Rodríguez-Flores et al., 2019).

We found that modularity was not significantly related with habitat occupancy but rather with morphological specialization (see Maruyama et al., 2014). Interestingly, both Hermit species formed modules integrated by only one species. Differences in bill length and curvature may promote specialization in specific floral morphologies, as reported by Rodríguez-Flores \& Stiles (2005) for the Colombian Amazon. The Hermits clade is considered the most specialized hummingbird group in regard to food resources and is highly diverse in the rainforests of South America (Rodríguez-Flores \& Stiles, 2005). Given that several plant species were visited exclusively by $P$. longirostris and $P$. striigularis, these hummingbirds could be acting as "key" species for the maintenance of the plant community (Araújo et at., 2018b). Hermits have been previously reported to play this role in other studies and to interact with more plants than other hummingbird species, for example, Phaethornis eurynome in the Atlantic rainforest (VizentinBugoni, Maruyama \& Sazima, 2014) and P. petrei in the Neotropical savanna of Brazil (Maruyama et al., 2014; Araújo, Hoffmann \& Sazima 2018). The two Emerald species, unlike the Hermits, were also observed feeding in canopy trees, always on non-specialized flowers where nectar is easily accessible (for example Inga vera in Fabaceae and Quararibea funebris in Bombacaceae). Additionally, in the understory, the role of the two Emerald species was more important for plant species with less restrictive morphological floral barriers, where they usually behave as territorial. Thus, in the absence of morphological specialization, the dominance hierarchy, which is correlated with body size, might play an important role in the Emeralds' 
557 niche portioning (Rodríguez-Flores \& Arizmendi, 2016, López-Segoviano, Bribiesca \& 558 Arizmendi, 2018; Márquez-Luna et al., 2019).

559 Contrary to expectations, we did not find higher floral integration in specialized modules or 560 differences between habitats. Some studies have reported the absence of evidence for pollinator561 mediated selection on correlated traits (e.g., Conner, 2002; Herrera et al., 2002; Meng et al., 562 2008). In both studied habitats, Phaethornis longirostris and P. striigularis were the only visitors 563 to many plant species, which was consequently reflected in the floral integration. Plant species 564 with specialized pollination systems should experience stronger or more consistent stabilizing or 565 directional selection on floral traits than species with generalized pollination (Rosas-Guerrero et 566 al., 2011). However, high covariation among floral and vegetative traits could be the default 567 situation (Armbruster et al., 1999).

568 In this context, pollination by various functional groups (e.g., Stromanthe macrochlamys) 569 would decrease the homogeneity of their pollination and, as a result, the correlational selection 570 on relevant floral characters and nectar properties (Berg, 1960; Ordano et al., 2008). For this 571 reason, the fact of not having considered other invertebrate visitors should not alter our 572 hypothesis, since specialized modules are less likely to be visited by other pollinators taxa. Some 573 studies such as Rosas-Guerrero et al. (2011) on Ipomoea and Pérez and Arroyo \& Medel (2007) 574 on Schizanthus support the idea that floral integration in pollinator-dependent species is shaped 575 by pollinator-mediated selection and is stronger in specialized relationships. However, these 576 studies tested differences between different functional groups of pollinators or morphospecies, 577 for example, plant species with bird-pollination and insect-pollination systems. Thus, differences 578 can be higher across plant species with different pollination systems when comparisons are 579 conducted among species in the same family. Herein, all plants of the assembly received legitimate visits from hummingbirds despite differences in their floral specialization.

Studies on plant-pollination mutualistic networks have provided important information for understanding the underlying processes that structure communities. However, the impact of pollinators on their nutritional plants, especially those with a greater degree of specificity, has received little attention. Herein, we used a new approach with the aim of linking the underlying network structuring processes with the consequent modularity related to ecological specialization and the consequences for phenotypic floral integration in two adjacent habitats in the Lacandona rainforest of Mexico. However, we noted a main limitation in our study, which is the low number of modules and pollination networks that can limited the assessed relationships between ecological specialization of modules and their phenotypic floral integration. To assess whether specialized modules are characterized by higher phenotypic floral integration one would need larger datasets of both the number of modules and pollination networks as to make generalizations about processes related to the modular organization of plant-hummingbird networks in terms of morphological specialization (i.e. phenotypic floral integration). Therefore, future work reviewing plant-hummingbird interactions and levels of flower integration would include datasets in a wide region to obtain a higher number of specialized or generalist modules and networks of various sizes. Although the number of modules and network size were the main 
597 limitations in our study to properly assess the relationships between ecological specialization of

598

599

600

601

602

603

604

605

606

607

608

609

610

611

612

613

614

615

616

617

618

619

620

621

622

623

624

625

626

627

628

629

630

631

632

633

634

635

636

modules and their phenotypic floral integration, it is also possible that the establishment of modules failed because the interaction network was built based on the legitimate visitation rates of floral visitors (potential pollinators) and not based on their pollinating efficiency of each hummingbird species. Therefore, we also suggest pollination experiments to determine the effectiveness and relative role of each visitor as pollinators and the breeding system of the plants in the networks, as alternatives to determine the number and specialization levels of modules. Clearly, this is a critical question for future research to address.

\section{Conclusions}

Mutualistic networks vary in their number of connections and the strength of interactions among species with distinct ecological specializations. Herein, we found that the plant composition of two adjacent habitats in the Lacandona rainforest may impact some of the structural parameters of the studied hummingbird-plant networks. Although the plant assemblages were distinct, the two habitats were highly interconnected by the hummingbirds, meaning that they formed a single interaction network. Forbidden links and trait matching were important mechanisms shaping the network topology, and they showed some patterns according to the specialization of the species involved and habitat sampled. Modularity was associated with morphological specialization and, indirectly, with the habitat affinity of species. However, the low number of modules and pollination networks in our study limited our assessment of how ecological specialization affects phenotypic floral integration among modules. Future research should seek to include datasets in a wide region to obtain a higher number of specialized or generalist modules and networks of various sizes, in order to delineate further the relationship between plant-hummingbird interactions and levels of flower integration.

\section{Acknowledgements}

We thank Natura Mexicana A.C., especially Javier de la Maza and Julia Carabias for the logistical support and allowing access to their facilities. We thank the staff of the Estación Biológica Chajul for trail maintenance, security, and accommodation. We thank Stuart Pimm, Pietro Kiyoshi Maruyama, and one anonymous reviewer who provided constructive comments that improved the manuscript. JI-P thanks Sergio Izquierdo and Fulvio Eccardi for being a constant source of inspiration as well as Posgrado en Ciencias Biológicas (Universidad Nacional Autónoma de México) and Universidad Autónoma de Tlaxcala for the logistical support, fieldwork equipment, and supplies. This work constitutes the partial fulfillment of JI-P's doctorate at the Universidad Nacional Autónoma de México. This paper is dedicated to the memory of Ricardo Frias, who suddenly passed in April 2020. He was a tireless defender of the Lacandona rainforest and considerably improved this manuscript with his invaluable comments and ideas.

\section{References}

Peer) reviewing PDF | (2020:07:50913:4:0:NEW 25 Jan 2021) 
637 Abrahamczyk S, Kessler M. 2010. Hummingbird diversity, food niche characters, and 638 assemblage composition along a latitudinal precipitation gradient in the Bolivian lowlands. 639 Journal of Ornithology 151:615-625 DOI 10.1007/s10336-010-0496-x.

640

641

642

643

644

645

646

647

648

649

650

651

652

653

654

655

656

657

658

659

660

661

662

663

664

665

666

667

668

669

670

671

672

673

674

675
Abrahamczyk S, Kessler M. 2015. Morphological and behavioural adaptations to feed on nectar: how feeding ecology determines the diversity and composition of hummingbird assemblages. Journal of Ornithology 156:333-347 DOI 10.1371/journal.pone.0027115.

Almeida-Neto M, Guimarães P, Guimarães PR, Loyola RD, Ulrich W. 2008. A consistent metric for nestedness analysis in ecological systems: reconciling concept and measurement. Oikos 117:1227-1239 DOI 10.1111/j.0030-1299.2008.16644.x.

Almeida-Neto M, Ulrich W. 2011. A straightforward computational approach for measuring nestedness using quantitative matrices. Environmental Modelling \& Software 26:173-178. DOI 10.1016/j.envsoft.2010.08.003.

Anderson IA, Busch JW. 2006. Relaxed pollinator-mediated selection weakens floral integration in self-compatible taxa of Leavenworthia (Brassicaceae). American Journal of Botany 93:860-867 DOI 10.3732/ajb.93.6.860.

Araújo FP, Sazima M, Oliveira PE. 2013. The assembly of plants used as nectar sources by hummingbirds in a Cerrado area of Central Brazil. Plant Systematics and Evolution 299:11191133 DOI 10.1007/s00606-013-0783-0.

Araújo FP, Hoffmann D, Sazima M. 2018. The planalto hermit, Phaethornis pretrei-a key species in a Neotropical savanna community in Central Brazil. Journal of Natural History 52:2385-2396 DOI 10.1080/00222933.2018.1536767.

Araujo AC, Martín González AM, Sandel B, Maruyama PK, Fischer E, Vizentin-Bugoni J, Araújo FP, Coelho AG, Faria RR, Kohler G, Las-Casas FMG, Lopes AV, Machado AO, Machado CG, Machado IC, McGuire JA, Moura AC, Oliveira GM, Oliveira PE, Rocca MA, Rodrigues LC, Rodrigues M, Rui AM, Sazima I, Sazima M, Varassin IG, Wang Z, Dalsgaard B, Svenning JC. 2018. Spatial distance and climate determine modularity in a crossbiomes plant-hummingbird interaction network in Brazil. Journal of Biogeography 45:18461858 DOI 10.1111/jbi.13367.

Arizmendi MC, Ornelas JF. 1990. Hummingbirds and their floral resources in a tropical dry forest in Mexico. Biotropica 22:172-180 DOI 10.2307/2388410.

PeerJ reviewing PDF | (2020:07:50913:4:0:NEW 25 Jan 2021) 
676 Arizmendi MC, Berlanga H. 2014. Colibríes de México y Norteamérica. México: CONABIO, 677160.

678

679

680

681

682

683

684

685

686

687

688

689

690

691

692

693

694

695

696

697

698

699

700

701

702

703

704

705

706

707

708

709

710

711

712

713

714
Armbruster WS. 1991. Multilevel analysis of morphometric data from natural plant populations: insights into ontogenetic, genetic, and selective correlations in Dalechampia scandens. Evolution 45:1229-1244. DOI 10.1111/j.1558-5646.1991.tb04389.x.

Armbruster WS, Di Stilio VNS, Tuxill JD, Flores TC, Velásquez Runk JL. 1999. Covariance and decoupling of floral and vegetative traits in nine Neotropical plants: a re-evaluation of Berg's correlation-pleiades concept. American Journal of Botany 86:39-55 DOI $10.2307 / 2656953$.

Barber MJ. 2007. Modularity and community detection in bipartite networks. Physical Review E 76:066102. DOI 10.1103/PhysRevE.76.066102.

Bascompte J, Jordano P, Melián CJ, Olesen JM. 2003. The nested assembly of plant animal mutualistic networks. Proceedings of the National Academy of Sciences, USA 100:9383-9387 DOI 10.1073/pnas.1633576100.

Bascompte J, Jordano P, Olesen JM 2006. Asymmetric coevolutionary networks facilitate biodiversity maintenance. Science 312:431-433. DOI 10.1126/science.1123412.

Bascompte J, Jordano P. 2007. Plant-animal mutualistic networks: the architecture of biodiversity. Annual Review of Ecology, Evolution, and Systematics 38:567-593 DOI 10.1146/annurev.ecolsys.38.091206.095818.

Bascompte J, Jordano P. 2013. Mutualistic networks. Princeton: Princeton University Press.

Bastolla U, Fortuna MA, Pascual-García A, Ferrera A, Luque B, Bascompte J. 2009. The architecture of mutualistic networks minimizes competition and increases biodiversity. Nature 458:1018 DOI 10.1038/nature07950.

Belmaker J, Sekercioglu CH, Jetz W. 2012. Global patterns of specialization and coexistence in bird assemblages. Journal of Biogeography 39:193-203 DOI 10.1111/j.13652699.2011.02591.x.

Berg RL. 1960. The ecological significance of correlation pleiades. Evolution 14:171-180 DOI 10.1111/j.1558-5646.1960.tb03076.x.

Peer) reviewing PDF | (2020:07:50913:4:0:NEW 25 Jan 2021) 
715 Bergamo PJ., Wolowski M, Maruyama PK, Vizentin-Bugoni J, Carvalheiro LG, Sazima, 716 M. 2017. The potential indirect effects among plants via shared hummingbird pollinators are

717

718

719

720

721

722

723

724

725

726

727

728

729

730

731

732

733

734

735

736

737

738

739

740

741

742

743

744

745

746

747

748

749

750

751

752

753

754 structured by phenotypic similarity. Ecology 98:1849-1858 DOI 10.1002/ecy.1859.

Bergamo PJ, Wolowski M, Maruyama PK, Vizentin-Bugoni J, Sazima M. 2018. Trait patterns across space and time suggest an interplay of facilitation and competition acting on Neotropical hummingbird-pollinated plant communities. Oikos 127:1690-1700 DOI 10.1111/oik.05571.

Bissell EK, Diggle PK. 2008. Floral morphology in Nicotiana: architectural and temporal effects on phenotypic integration. International Journal of Plant Sciences 169:225-240 DOI 10.1086/523875.

Blüthgen N, Menzel F, Hovestadt T, Fiala B, Blüthgen N. 2007. Specialization, constraints, and conflicting interests in mutualistic networks. Current Biology 17:341-346 DOI 10.1016/j.cub.2006.12.039.

Bosch J, Martín González AM, Rodrigo A, Navarro D. 2009. Plant-pollinator networks: adding the pollinator's perspective. Ecology Letters 12:409-419 DOI 10.1111/j.14610248.2009.01296.x.

Carabias J, De la Maza J, Cadena R. 2015. Conservación y desarrollo sustentable en la Selva Lacandona. 25 años de actividades y experiencias. Ciudad de México: Natura y Ecosistemas Mexicanos.

Conner JK. 2002. Genetic mechanisms of floral trait correlations in a natural population. Nature 420:407-410 DOI 10.1038/nature01105.

Conner J, Via S. 1993. Patterns of phenotypic and genetic correlations among morphological and life-history traits in wild radish, Raphanus raphanistrum. Evolution 47:704-711 DOI 10.1111/j.1558-5646.1993.tb02128.x.

Dalsgaard B, González AMM, Olesen JM, Ollerton J, Timmermann, A, Andersen LH, Tossas AG. 2009. Plant-hummingbird interactions in the West Indies: floral specialisation gradients associated with environment and hummingbird size. Oecologia 159:757-766 DOI 10.1007/s00442-008-1255-z.

Dalsgaard B, Magård E, Fjeldså J, Martín González AM, Rahbek C, Olesen JM, Ollerton J, Alarcón R, Araujo AC, Cotton PA, Lara C, Machado CG, Sazima I, Sazima M, Timmermann A, Watts S, Sandel B, Sutherland WJ, Svenning JC. 2011. Specialization in 
755

756

757

758

759

760

761

762

763

764

765

766

767

768

769

770

771

772

773

774

775

776

777

778

779

780

781

782

783

784

785

786

787

788

789

790

791

792

793

794 plant-hummingbird networks is associated with species richness, contemporary precipitation and quaternary climate-change velocity. PLOS ONE 6:e25891 DOI 10.1371/journal.pone.0025891.

Danieli-Silva A, Souza JMT, Donatti, AJ, Campos RP, Vicente-Silva J, Freitas L, Varassin IG. 2012. Do pollination syndromes cause modularity and predict interactions in a pollination network in tropical high-altitude grasslands? Oikos 121:35-43 DOI 10.1111/j.16000706.2011.19089.x.

Dehling DM, Jordano P, Schaefer HM, Böhning-Gaese K, Schleuning M. 2016. Morphology predicts species' functional roles and their degree of specialization in plant-frugivore interactions. Proceedings of the Royal Society B: Biological Sciences 283:20152444. DOI 10.1098/rspb.2015.2444.

Dormann CF, Gruber B, Fründ J. 2008. Introducing the bipartite package: analyzing ecological networks. $R$ News 8:8.12.

Dormann CF, Strauss R. 2014. A method for detecting modules in quantitative bipartite networks. Methods in Ecology and Evolution 5:90-98 DOI 10.1111/2041-210X.12139.

Feinsinger, P. 1976. Organization of a tropical guild of nectarivorous birds. Ecological Monographs 46:257-291 DOI 10.2307/1942255.

Feinsinger P, Colwell RK. 1978. Community organization among Neotropical nectar-feeding birds. American Zoologist 18:779-795 DOI 10.1093/icb/18.4.779.

Fenster CB. 1991. Selection on floral morphology by hummingbirds. Biotropica 23:98-101 DOI $10.2307 / 2388696$.

\section{Fortuna MA, Stouffer DB, Olesen JM, Jordano P, Mouillot D, Krasnov BR, Poulin R,} Bascompte J. 2010. Nestedness versus modularity in ecological networks: two sides of the same coin?. Journal of Animal Ecology 79:811-817 DOI 10.1111/j.1365-2656.2010.01688.x.

\section{Guimarães PR, Rico-Gray V, Furtado dos Reis S, Thompson JN. 2006. Asymmetries in} specialization in ant-plant mutualistic networks. Proceedings of the Royal Society B: Biological Sciences 273:2041-2047 DOI 10.1098/rspb.2006.3548.

Guimarães JPR, Guimarães P. 2006. Improving the analyses of nestedness for large sets of matrices. Environmental Modelling \& Software 21:1512-1513 DOI

10.1016/j.envsoft.2006.04.002. 
799

800

801

802

803

804

805

806

807

808

809

810

811

812

813

814

815

816

817

818

819

820

821

822

823

824

825

826

827

828

829

830

831

832

833

834

Herrera CM, Cerdá X, Garcia MB, Guitián J, Medrano M, Rey PJ, Sánchez-Lafuente AM. 2002. Floral integration, phenotypic covariance structure and pollinator variation in bumblebeepollinated Helleborus foetidus. Journal of Evolutionary Biology 15:108-121 DOI 10.1046/j.1420-9101.2002.00365.x.

Ings TC, Montoya JM, Bascompte J, Blüthgen N, Brown, L, Dormann, CF, Edwards F, Figueroa D, Ute J, Jones JI, Lauridsen RB, Ledger ME, Lewis HM, Olesen JM, Van Veen FJF, Warren PH, Woodward G. 2009. Ecological networks-beyond food webs. Journal of Animal Ecology 78:253-269 DOI 10.1111/j.1365-2656.2008.01460.x.

Joppa,LN, Bascompte J, Montoya JM, Solé RV, Sanderson J, Pimm SL. 2009. Reciprocal specialization in ecological networks. Ecology Letters 12:961-9 DOI 10.1111/j.14610248.2009.01341.x.

Jordano P. 1987. Patterns of mutualistic interactions in pollination and seed dispersal: connectance, dependence asymmetries, and coevolution. The American Naturalist 129:657-677 DOI 10.1086/284665.

Lara C. 2006. Temporal dynamics of flower use by hummingbirds in a highland temperate forest in Mexico. Ecoscience 13:23-29 DOI 10.2980/11956860(2006)13[23:TDOFUB]2.0.CO;2.

Lewinsohn TM, Inácio Prado P, Jordano P, Bascompte J, Olesen JM. 2006. Structure in plant-animal interaction assemblages. Oikos 113:174-184 DOI 10.1111/j.00301299.2006.14583.x.

Ley AC, Claßen-Bockhoff R. 2009. Pollination syndromes in African Marantaceae. Annals of Botany 104:41-56. DOI 10.1093/aob/mcp106.

López-Segoviano G, Bribiesca R, Arizmendi MDC. 2018. The role of size and dominance in the feeding behaviour of coexisting hummingbirds. Ibis 160:283-292 DOI 10.1111/ibi.12543.

Maglianesi, MA, Blüthgen N, Böhning-Gaese K, Schleuning M. 2014. Morphological traits determine specialization and resource use in plant-hummingbird networks in the Neotropics. Ecology 95:3325-3334 DOI 10.1890/13-2261.1.

Maglianesi MA, Blüthgen N, Böhning-Gaese K, \& Schleuning M. 2014. Morphological traits determine specialization and resource use in plant-hummingbird networks in the Neotropics. Ecology 95:3325-3334 DOI 10.1890/13-2261.1. 
Maglianesi MA, Blüthgen N, Böhning-Gaese K, Schleuning M. 2015. Functional structure and specialization in three tropical plant-hummingbird interaction networks across an elevational gradient in Costa Rica. Ecography 38:1119-1128 DOI 10.1111/ecog.01538.

Márquez-Luna U, Lara C, Corcuera P, Valverde PL. 2019. Factors affecting the dominance hierarchy dynamics in a hummingbird assemblage. Current Zoology 65:261-268 DOI $10.1093 / \mathrm{cz} /$ zoy057.

Marquitti FMD, Guimarães JPR, Pires MM, Bittencourt LF. 2014. MODULAR: software for the autonomous computation of modularity in large network sets. Ecography 37:221-224 DOI 10.1111/j.1600-0587.2013.00506.x.

Maruyama PK, Oliveira GM, Ferreira C, Dalsgaard B, Oliveira PE. 2013. Pollination syndromes ignored: importance of non-ornithophilous flowers to Neotropical savanna hummingbirds. Naturwissenschaften 100:1061-1068 DOI 10.1007/s00114-013-1111-9.

Maruyama PK, Vizentin-Bugoni J, Oliveira GM, Oliveira PE, Dalsgaard B. 2014.

Morphological and spatio-temporal mismatches shape a Neotropical savanna plant-hummingbird network. Biotropica 46:40-747. DOI 10.1111/btp.12170.

Maruyama PK, Sonne J, Vizentin-Bugoni J, AM Martin González, Zanata TB, Abrahamczyk S, Alarcón R, Araujo AC, Araújo FP, Baquero AC, Chávez-González E, Coelho AG, Cotton PA, Dehling DM, Fischer E, Kohler G, Lara C, Las-Casas FMG, Machado AO, Machado CG, Maglianesi MA, Malucelli TS, Marín-Gómez OH, Oliveira PE, Ornelas JF, Ortiz-Pulido R, Ramírez-Burbano MB, Rocca MA, Rodrigues LC, RoseroLasprilla L, Rui AM, Sandel B, Svenning JCH, Tinoco BA, Varassin IG, Watts S, Rahbek C, Sazima M, Schleuning M, Dalsgaard B. 2018. Functional diversity mediates macroecological variation in plant-hummingbird interaction networks. Global Ecology and Biogeography 27:1186-1199. DOI 10.1111/geb.12776.

McGuire JA, Witt CC, Remsen JV, Dudley R, Altshuler DL. 2009. A higher-level taxonomy for hummingbirds. Journal of Ornithology 150:155-165 DOI 10.1073/pnas.0405260101.

Meng JL, Zhou XH, Zhao ZG, Du GZ. 2008. Covariance of floral and vegetative traits in four species of Ranunculaceae: a comparison between specialized and generalized pollination systems. Journal of Integrative Plant Biology 50:1161-1170 DOI 10.1111/j.17447909.2008.00722.x. 
874 Miranda F, Hernández E. 1963. Los tipos de vegetación de México y su clasificación.

875

876

877

878

879

880

881

882

883

884

885

886

887

888

889

890

891

892

893

894

895

896

897

898

899

900

901

902

903

904

905

906

907

908

909

910

911

912

Botanical Sciences 28:29-179 DOI 10.17129/botsci.1084.

Newman ME. 2006. Modularity and community structure in networks. Proceedings of the

National Academy of Sciences, USA 103:8577-8582 DOI 10.1073/pnas.0601602103.

Niovi Jones K, Reithel, JS. 2001. Pollinator-mediated selection on a flower color polymorphism in experimental populations of Antirrhinum (Scrophulariaceae). American Journal of Botany 88:447-454 DOI 10.2307/2657109.

Olesen JM, Jordano P. 2002. Geographic patterns in plant-pollinator mutualistic networks. Ecology 83:2416-2424 DOI 10.1890/0012-9658(2002)083[2416:GPIPPM]2.0.CO;2.

Olesen JM, Bascompte J, Dupont YL, Jordano P. 2006. The smallest of all worlds: pollination networks. Journal of Theoretical Biology 240:270-276 DOI 10.1016/j.jtbi.2005.09.014.

Olesen JM, Bascompte J, Dupont YL, Jordano P. 2007. The modularity of pollination networks. Proceedings of the National Academy of Sciences, USA 104:19891-19896 DOI $10.1073 /$ pnas.0706375104.

Ordano M, Fornoni J, Boege K, Domínguez CA. 2008. The adaptive value of phenotypic floral integration. New Phytologist 179:1183-1192 DOI 10.1111/j.1469-8137.2008.02523.x.

Olesen JM, Bascompte J, Dupont YL, Elberling H, Rasmussen C, Jordano P. 2011. Missing and forbidden links in mutualistic networks. Proceedings of the Royal Society B: Biological Sciences 278:725-732 DOI 10.1098/rspb.2010.1371.

Paton DC, Collins BG. 1989. Beaks and tongues of nectar-feeding birds: A review of morphology, function and performance, with intercontinental comparisons. Australian Journal of Ecology 14:473-506 DOI 10.1111/j.1442-9993.1989.tb01457.x.

Pérez F, Arroyo MT, Medel R. 2007. Phylogenetic analysis of floral integration in Schizanthus (Solanaceae): does pollination truly integrate corolla traits?. Journal of Evolutionary Biology 20:1730-1738 DOI 10.1111/j.1420-9101.2007.01393.x.

R Development Core Team. 2018. $R$ : a language and environment for statistical computing. Vienna: R Foundation for Statistical Computing. Available at http://www.R-project.org . 
913 Rico-Guevara A, Araya-Salas M. 2015. Beaks as daggers? A test for sexually dimorphic

914

915

916

917

918

919

920

921

922

923

924

925

926

927

928

929

930

931

932

933

934

935

936

937

938

939

940

941

942

943

944

945

946

947

948

949

950

951

weapons in a lekking hummingbird. Behavioral Ecology 26:21-29 DOI 10.1093/beheco/aru182.

Rodríguez-Flores CI, Stiles, FG. 2005. Análisis ecomorfológico de una comunidad de colibríes ermitaños (Trochilidae, Phaethorninae) y sus flores en la amazonia colombiana. Ornitología Colombiana 3:3-27

Rodríguez-Flores CI, Arizmendi MC. 2016. The dynamics of hummingbird dominance and foraging strategies during the Winter season in a highland community in Western Mexico.

Journal of Zoology 299:262-274 DOI 10.1111/jzo.12360.

Rodríguez-Flores CI, Ornelas JF, Wethington S, Arizmendi MC. 2019. Are hummingbirds generalists or specialists? Using network analysis to explore the mechanisms influencing their interaction with nectar resources. PLoS ONE 14:e021855 DOI 10.1371/journal.pone.0211855

\section{Rosas-Guerrero V, Quesada M, Armbruster WS, Pérez-Barrales R, Smith SD. 2011.}

Influence of pollination specialization and breeding system on floral integration and phenotypic variation in Ipomoea. Evolution: International Journal of Organic Evolution 65:350-364 DOI 10.1111/j.1558-5646.2010.01140.x.

Rzedowski, J, Huerta L. 1994. Vegetación de México. México: Limusa, Noriega Editores.

Santamaría L, Rodríguez-Gironés, MA. 2007. Linkage rules for plant-pollinator networks: trait complementarity or exploitation barriers?. PLoS Biology 5:e31. DOI 10.1371/journal.pbio.0050031.

Sazatornil FD, More M, Benitez-Vieyra S, Cocucci AA, Kitching IJ, Schlumpberger BO, Oliveira PE, Sazima M, Amorim FW. 2016. Beyond neutral and forbidden links: morphological matches and the assembly of mutualistic hawkmoth-plant networks. Journal of Animal Ecology 85:1586-1594 DOI 10.1111/1365-2656.12509.

Schneider CA, Rasband, WS, Eliceiri, KW. 2012. NIH Image to ImageJ: 25 years of image analysis. Nature Methods 9:671-675 DOI 10.1038/nmeth.2089.

Siebe C, Martínez-Ramos M, Segura-Warnholtz G, Rodríguez-Velázquez J, SánchezBeltrán S. 1996. Soil and vegetation patterns in the tropical rainforest at Chajul, southeast Mexico. In Proceedings of the International Congress on Soils of Tropical Forest Ecosystems 40-58.

Peer] reviewing PDF | (2020:07:50913:4:0:NEW 25 Jan 2021) 
952 Smith RA, Rausher MD. 2008. Selection for character displacement is constrained by the 953 genetic architecture of floral traits in the ivyleaf morning glory. Evolution 62:2829-2841 DOI 954 10.1111/j.1558-5646.2008.00494.x.

955

Sonne J, Zanata TB, Martín González AM. Torres NLC, Fjeldså, J, Colwell RK, Tinoco BA, Rahbek C, Dalsgaard B. 2019. The distributions of morphologically specialized hummingbirds coincide with floral trait matching across an Andean elevational gradient.

960 Biotropica 51:205-218 DOI 10.1111/btp.12637.

Sonne J, Vizentin-Bugoni J, Maruyama PK, Araujo AC, Chávez-González E, Coelho AG, Cotton PA, Marín-Gómez OH, Lara C, Lasprilla LR, Machado CG, Maglianesi MA, Malucelli TS, Martín González AM, Oliveira GM, Oliveira PE, Ortiz-Pulido R, Rocca MA, Rodrigues LC, Sazima I, Simmons BI, Tinoco B, Varassin IG, Vasconcelos MF, O'Hara B, Schleuning M, Rahbek C, Sazima M, Dalsgaard B. 2020. Ecological mechanisms explaining interactions within plant-hummingbird networks: morphological matching increases towards lower latitudes. Proceedings of the Royal Society B, 287:20192873 DOI 10.1098/rspb.2019.2873.

969

Stebbins GL. 1970. Adaptive radiation of reproductive characteristics in angiosperms, I:

971

972

Stiles FG. 1975. Ecology, flowering phenology, and hummingbird pollination of some Costa

975

Stiles FG. 1978. Temporal organization of flowering among the hummingbird foodplants of a tropical wet forest. Biotropica 10:194-210. DOI 10.2307/2387905.

978

Stiles FG. 1995. Behavioral, ecological and morphological correlates of foraging for arthropods by the hummingbirds of a tropical wet forest. The Condor 97:853-878 DOI 10.2307/1369527.

981

Sugihara G, Ye H. 2009. Cooperative network dynamics. Nature 458: 979-980 DOI

983 10.1038/458979a.

984

Thomson JD, Wilson P. 2008. Explaining evolutionary shifts between bee and hummingbird 169:23-38 DOI 10.2307/2265575.

988 
992

993

994

995

996

997

998

999

1000

1001

1002

1003

1004

1005

1006

1007

1008

1009

1010

1011

1012

1013

1014

1015

1016

1017

1018

1019

1020

1021

1022

1023

1024

1025

1026

1027

1028

1029

1030

1031

Vázquez DP, Aizen MA. 2003. Null model analyses of specialization in plant-pollinator interactions. Ecology 84:2493-2501 DOI 10.1890/02-0587.

Vázquez DP, Blüthgen N, Cagnolo L, Chacoff N. 2009. Uniting pattern and process in plantanimal mutualistic networks: a review. Annals of Botany 103:1445-1457 DOI 10.1093/aob/mcp057.

Vázquez DP, Chacoff NP, Cagnolo L. 2009. Evaluating multiple determinants of the structure of mutualistic networks. 2009. Ecology 90:2039-2046 DOI 10.1890/08-1837.1.

Verdú M, Valiente-Banuet A. 2008. The nested assembly of plant facilitation networks prevents species extinctions. The American Naturalist 172:751-760 DOI 10.1086/593003.

Vizentin-Bugoni J, Maruyama PK, Sazima M. 2014. Processes entangling interactions in communities: forbidden links are more important than abundance in a hummingbird-plant network. Proceedings of the Royal Society B: Biological Sciences 281:20132397 DOI 10.1098/rspb.2013.2397.

Vizentin-Bugoni J, Maruyama PK, Debastiani VJ, Duarte LDS, Dalsgaard B, Sazima M. 2016. Influences of sampling effort on detected patterns and structuring processes of a Neotropical plant-hummingbird network. Journal of Animal Ecology 85:262-272 DOI $10.1111 / 1365-2656.12459$.

Wagner GP. 1984. On the eigenvalue distribution of genetic and phenotypic dispersion matrices: evidence for a nonrandom organization of quantitative character variation. Journal of Mathematical Biology 21:77-95. DOI 10.1007/BF00275224.

Waser NM, Chittka L, Price MV, Williams NM, Ollerton J. 1996. Generalization in pollination systems, and why it matters. Ecology 77:1043-1060 DOI 10.2307/2265575.

Wolf LL, Stiles FG, Hainsworth FR. 1976. Ecological organization of a tropical, highland hummingbird community. Journal of Animal Ecology 45:349-379. DOI 10.2307/3879.

Zanata T, Dalsgaard B, Passos FC, Cotton PA, Ropert JJ, Maruyama PK, Fischer E, Schleuning M, Martín González AM, Vizentin-Bugoni J, Franklin DC, Abrahamczyk S, Alárcon R, Araújo AC, Aráujo FP, Azevedo-Junior SM, Baquero AC, Böhning-Gaese K, Carstensen DW, Chupil H, Coelho AG, Faria RR, Horák D, Ingversen TT, Janecek S, Kohler G, Lara C, Las-Casas FMG, Lopes AV, Machado AO, Machado CG, Machado IC, Maglianesi MA, Malucelli TS, Mohd-Azlan J, Moura AC, Oliveira GM, Oliveira PE,

Peer) reviewing PDF | (2020:07:50913:4:0:NEW 25 Jan 2021) 
1032 Ornelas JF, Riegert J, Rodrigues LC, Rosero-Lasprilla L, Rui AM, Sazima M, Schmid B, 1033 Sedlácek O, Timmermann A, Vollstädt MGR, Wang Z, Watts S, Rahbek C, Varassin IG. 1034 2017. Global patterns of interaction specialization in bird-flower networks. Journal of 1035 Biogeography 44:1891-910. DOI 10.1111/jbi.13045. 


\section{Figure 1}

Networks of hummingbirds and their nectar plants with identified modules indicated by colors.

(A) Ecological network comprised by the plant and the hummingbird assemblages from the two habitats, identifying modules for plants and pollinators. (B) Ecological network obtained from the rainforest. (C) Ecological network from the savanna habitat. The thickness of the lines is proportional to the strength of the pairwise interactions. Circles from A to Z represent the plant species: (A) Aechmea tillandsioides, (B) Aechmea bracteata, (C) Androlepis skinneri, (D) Billbergia viridiflora, (E) Bromelia pinguin, (F) Calathea lutea, (G) Catopsis berteroniana, (H) Costus pictus, (I) Costus scaber, (J) Erythrina folkersii, (K) Heliconia aurantiaca, (L) Heliconia collinsiana, (M) Heliconia latispatha, (N) Heliconia librata, (0) Heliconia wagneriana, (P) Justicia aurea, (Q) Malvaviscus arboreus, (R) Odontonema callistachyum, (S) Odontonema tubaeforme, (T) Palicourea triphylla, (U) Psychotria poeppigiana, (V) Stromanthe macrochlamys, (W) Tillandsia bulbosa, (X) Tillandsia pruinosa, (Y) Tillandsia streptophylla, (Z) Vriesea heliconioides. Circles H1-2 represent the hummingbird Hermits clade: Phaethornis longirostris ( $\mathrm{H} 1)$ and Phaethornis striigularis $(\mathrm{H} 2)$. Circles E1-2 represent the hummingbird Emeralds clade: Chlorestes candida (E1) and Amazilia tzacatl (E2). Hummingbird illustration credit: Marco Antonio Pineda Maldonado/Banco de Imágenes CONABIO. Photo credit: Jaume Izquierdo-Palma 

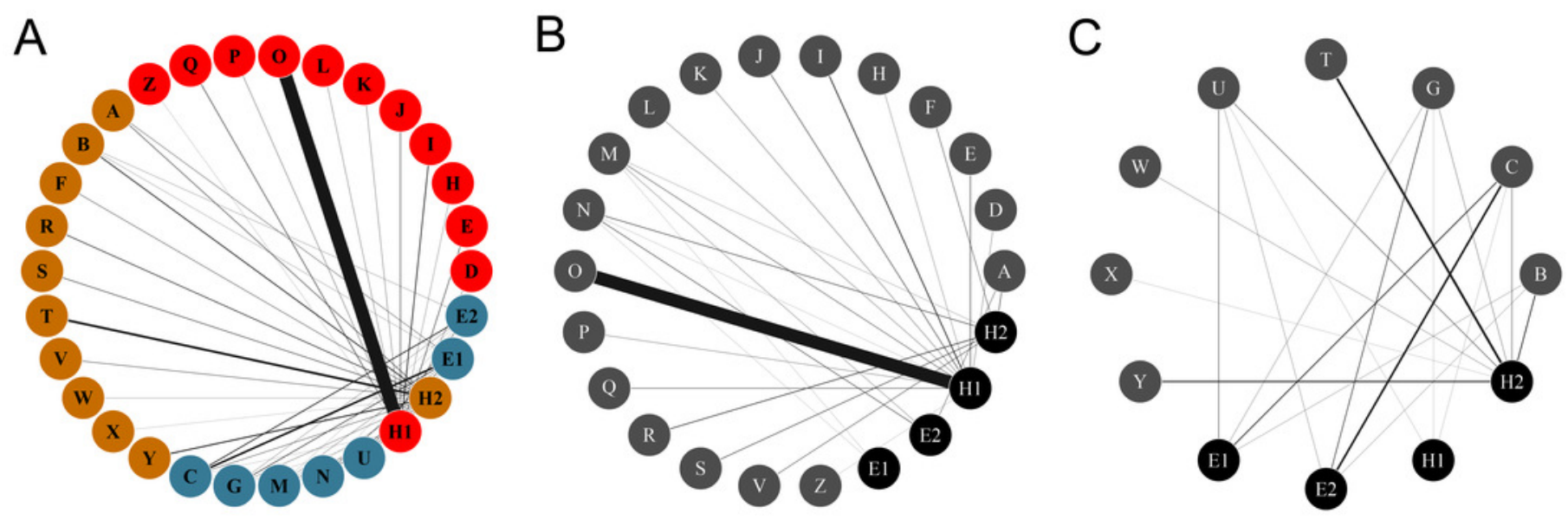


\section{Figure 2}

(A) Rainforest and (B) savanna habitats with some plant species (C-J) from their assemblages belonging to different families photographed in the study site.

Plant species correspond to: (C) Justicia aurea (Acanthaceae), (D) Heliconia wagneriana (Heliconiaceae), (E) Bromelia pinguin (Bromeliaceae) and (F) Costus scaber (Costaceae) from the rainforest assemblage (A); and (G) Palicourea triphylla (Rubiaceae), (H) Tillandsia pruinosa (Bromeliaceae), (I) Psychotria poeppigiana (Rubiaceae) and (J) Androlepis skinneri (Bromeliaceae) from the savanna assemblage (B). Photo credit: Jaume Izquierdo-Palma. 


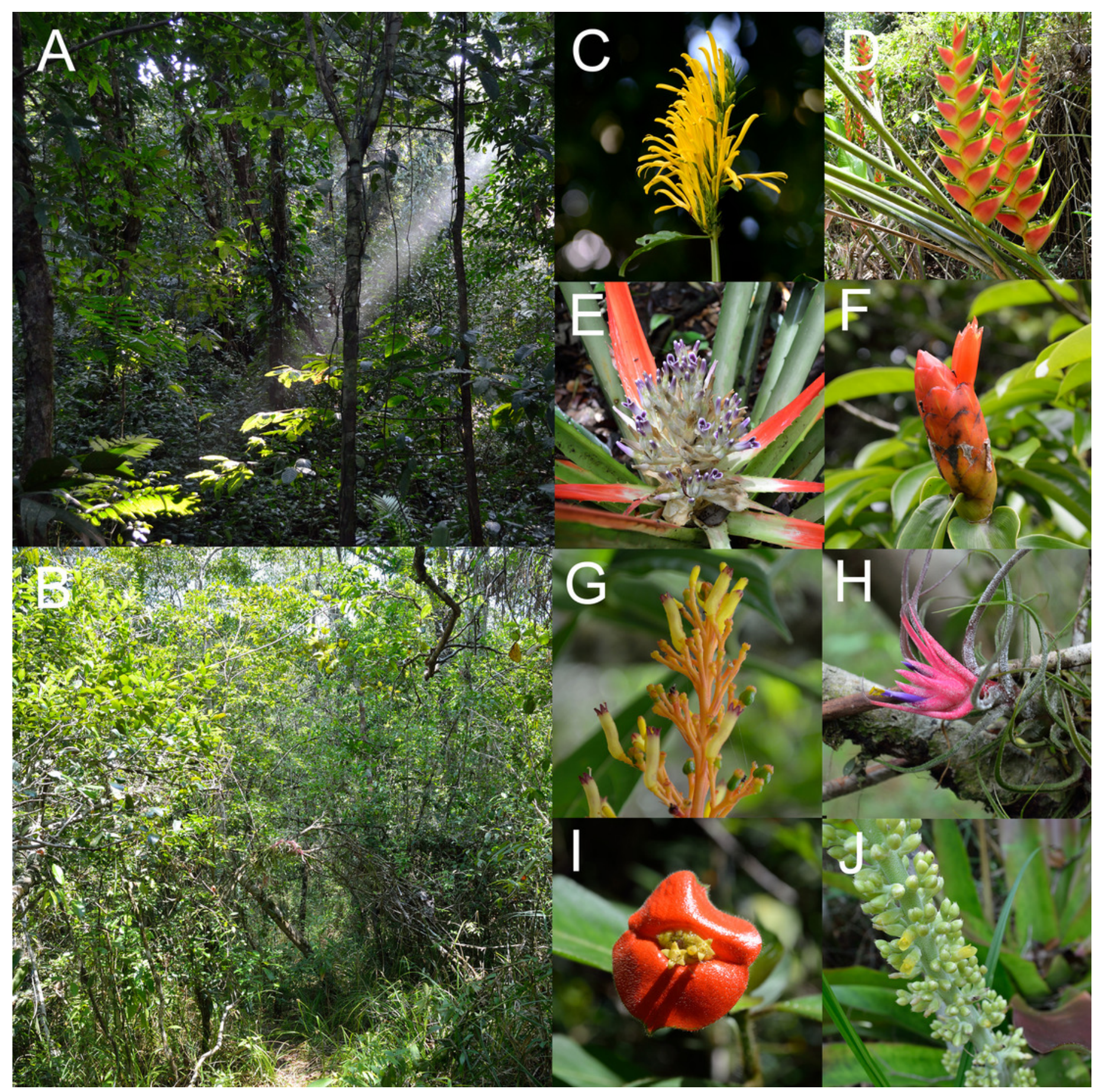




\section{Figure 3}

Average floral integration index (PINT) found in each module.

Colors indicate the modules found in the complete network with the rainforest and savanna plant assemblages together. One module is formed by Amazilia tzacatl ( $A$. tzacatl) and Chlorestes candida (Ch. candida), one by Phaethornis striigularis (P. striigularis) and one by Phaethornis longirostris (P. longirostris).

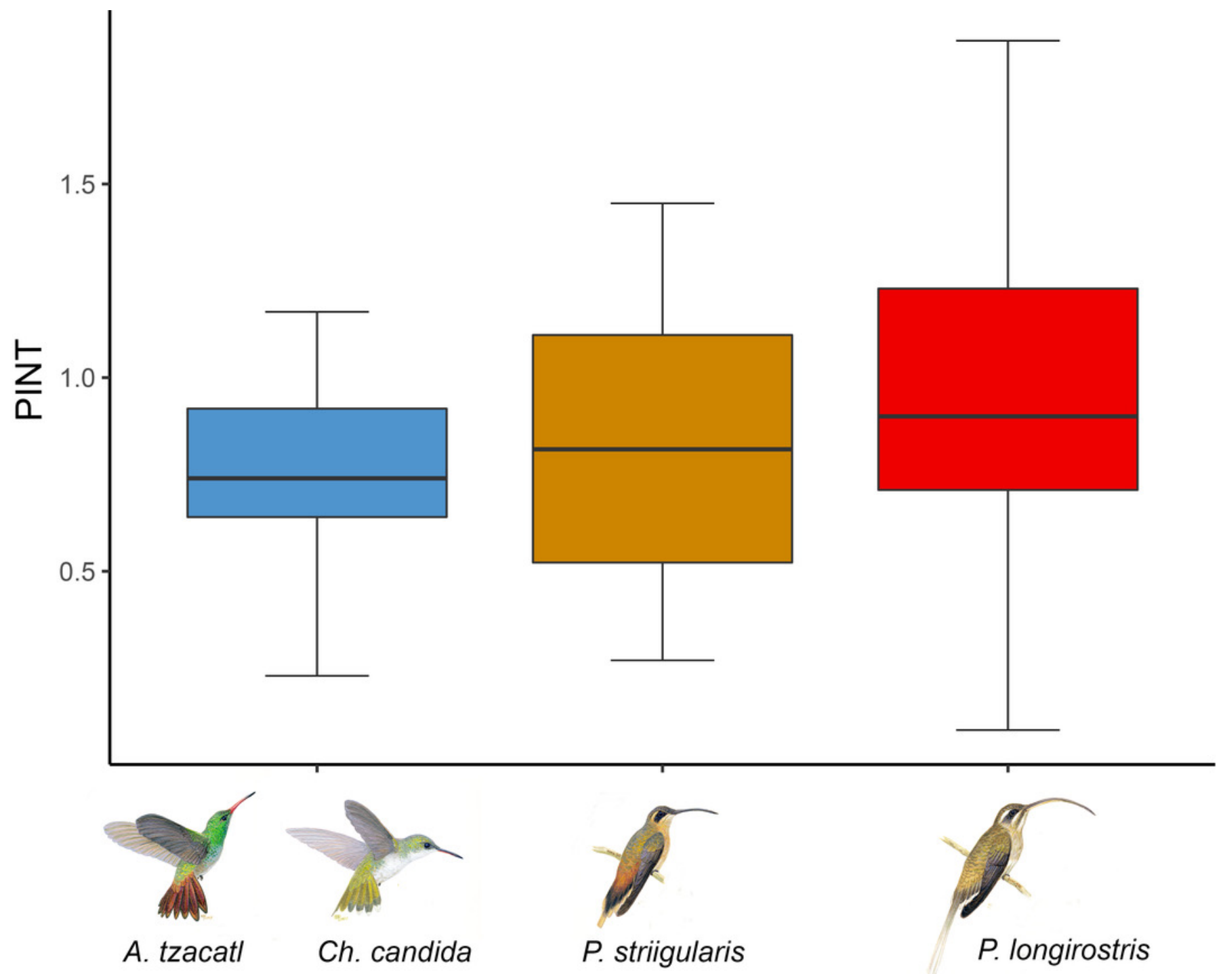




\section{Figure 4}

Trait matching between corresponding pairs of morphological traits in three plant species and their exclusive hummingbird visitor, Phaethornis longirostris, in the study area.

Plant species correspond to: (A) Billbergia viridiflora (Bromeliaceae), (B) Heliconia aurantiaca (Haliconiaceae), and (C) Heliconia wagneriana (Heliconiaceae). Photo credit: Jaume IzquierdoPalma.

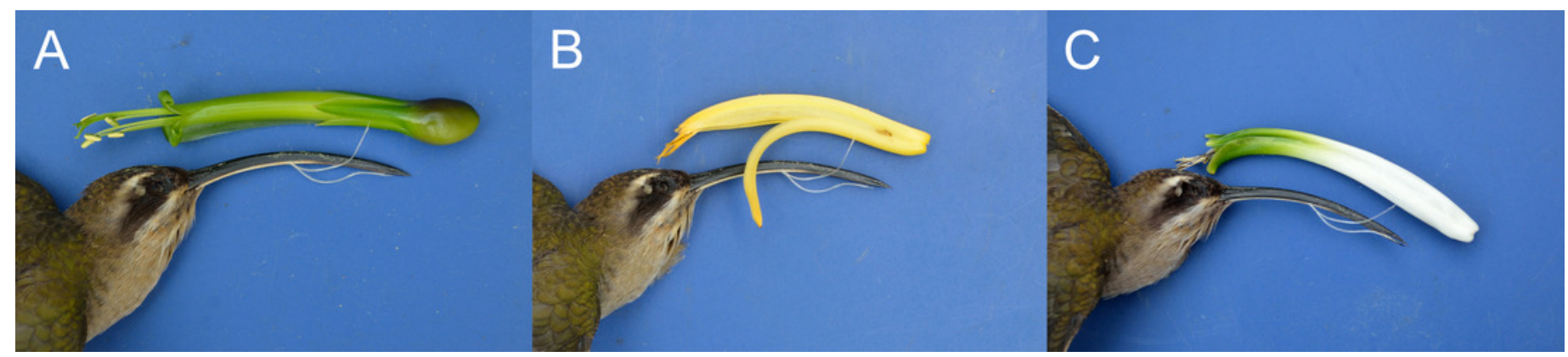




\section{Table $\mathbf{1}$ (on next page)}

Contribution of morphological and nectar variables in the PCA analysis.

Variables contribution in the PCA analysis related to floral types according to the floral measurements (corolla length and curvature) and nectar metrics (volume and concentration) from plant species visited legitimately by hummingbirds in the study area. Total variance explained: PC1 (50.5\%), PC1 (19.5\%) and PC3 (18.18\%). 


\begin{tabular}{lccc}
\hline & PC1 & PC2 & PC3 \\
\hline Corolla length $(\mathbf{m m})$ & -0.724813 & -0.554099 & 0.104947 \\
Curvature (degrees) & -0.732850 & 0.057970 & 0.572058 \\
Nectar volume $(\boldsymbol{\mu l})$ & -0.710645 & -0.131267 & -0.617961 \\
Nectar concentration $\left({ }^{\circ} \mathbf{B x}\right)$ & -0.672742 & 0.672500 & -0.083464
\end{tabular}

1

2

3 


\section{Table 2 (on next page)}

Plant species contribution in the three principal components according to their floral and nectar measures.

Plant species contribution in the PCA analysis related to floral types according to their floral measures and nectar metrics of plants from the rainforest and the savanna assemblages. Family is indicated for each plant species. 


\begin{tabular}{|c|c|c|c|c|}
\hline & PC1 & PC2 & PC3 & Family \\
\hline Justicia aurea & -0.20912 & -1.38380 & 0.63834 & Acanthaceae \\
\hline Odontonema callistachyum & 1.54261 & -0.33942 & 0.78373 & Acanthaceae \\
\hline Odontonema tubaeforme & 0.26520 & 0.01332 & 1.74687 & Acanthaceae \\
\hline Aechmea tillandsioides & 1.05441 & 0.41421 & -0.49576 & Bromeliaceae \\
\hline Billbergia viridiflora & -1.32573 & 0.53509 & 0.88704 & Bromeliaceae \\
\hline Vriesea heliconioides & 0.35424 & 0.19862 & 0.72610 & Bromeliaceae \\
\hline Costus pictus & -2.96626 & 0.26148 & -0.55565 & Costaceae \\
\hline Costus scaber & -1.85085 & -0.13146 & 0.73183 & Costaceae \\
\hline Erythrina folkersii & 0.36308 & -2.31230 & -0.23929 & Fabaceae \\
\hline Heliconia aurantiaca & -1.53691 & -0.74214 & 0.29206 & Heliconiaceae \\
\hline Heliconia collinsiana & -2.58638 & -0.00323 & -0.54788 & Heliconiaceae \\
\hline Heliconia latispatha & -1.44918 & -0.29543 & -2.40521 & Heliconiaceae \\
\hline Heliconia librata & 0.41088 & 0.55341 & -0.39214 & Heliconiaceae \\
\hline Heliconia wagneriana & -1.02959 & -0.66353 & 0.50188 & Heliconiaceae \\
\hline Malvaviscus arboreus & 0.80604 & -0.78644 & -0.57486 & Malvaceae \\
\hline Calathea lutea & -1.40318 & 2.44192 & 0.32448 & Marantaceae \\
\hline Stromanthe macrochlamys & 1.56472 & 1.00354 & -0.29824 & Marantaceae \\
\hline Aechmea bracteata & 1.89721 & 0.36199 & -0.16328 & Bromeliaceae \\
\hline Androlepis skinneri & 1.07203 & 0.24615 & -1.24655 & Bromeliaceae \\
\hline Catopsis berteroniana & 1.68092 & -0.31029 & -0.72595 & Bromeliaceae \\
\hline Tillandsia streptophylla & 0.34628 & -0.13030 & 0.57020 & Bromeliaceae \\
\hline Tillandsia bulbosa & 0.43713 & -0.06154 & 0.69774 & Bromeliaceae \\
\hline Palicourea triphylla & 1.27467 & 0.39677 & 0.13276 & Rubiaceae \\
\hline Psychotria poeppiginiana & 1.28778 & 0.73338 & -0.38821 & Rubiaceae \\
\hline
\end{tabular}




\section{Table 3 (on next page)}

Hummingbird species (or groups) associated with the average floral traits across plant species they visited.

Average floral measures and nectar metrics across plant species visited exclusively by Phaethornis longirostris, Phaethornis striigularis and various visitors (Amazilia tzacatl, Chlorestes candida and Phaethornis sp.). 


\begin{tabular}{|c|c|c|c|c|c|c|}
\hline Species & Corolla lenght (mm) & Stamen length (mm) & Style length (mm) & Curvature (degrees) & Nectar volume $(\mu \mathrm{l})$ & Nectar concentration $\left({ }^{\circ} \mathbf{B x}\right)$ \\
\hline Phaethornis longirostris & $53.45 \pm 15.96(n=11)$ & $57.46 \pm 7.15(n=10)$ & $56.09 \pm 6.92(n=10)$ & $13.45 \pm 6.75(n=9)$ & $26.75 \pm 16.74(n=10)$ & $24.19 \pm 4.73(n=10)$ \\
\hline Phaethornis striigularis & $22.79 \pm 11.49(n=8)$ & $26.48 \pm 14.92(n=8)$ & $26.42 \pm 16.35(n=7)$ & $9.24 \pm 5.93(n=8)$ & $5.98 \pm 5.16(n=7)$ & $23.54 \pm 6.30(n=7)$ \\
\hline $\begin{array}{l}\text { Amazilia tzacatl, Chlorestes } \\
\text { candida, Phaethornis sp. }\end{array}$ & $18.30 \pm 9.28(n=7)$ & $17.56 \pm 11.13(n=7)$ & $20.04 \pm 10.98(n=6)$ & $1.62 \pm 2.77(n=7)$ & $24.06 \pm 24.68(n=7)$ & $22.55 \pm 2.47(n=7)$ \\
\hline
\end{tabular}

2

3 